DOI 10.1515/linpo-2017-0004

\title{
Strategic actions according to Jürgen Habermas - some critical remarks from the transcendental-pragmatic procedure viewpoint
}

\author{
Magdalena Filipiak \\ Institute of Philosophy, Adam Mickiewicz University in Poznań \\ m.filipiak@amu.edu.pl
}

\begin{abstract}
Magdalena Filipiak. Strategic actions according to Jürgen Habermas - some critical remarks from the transcendental-pragmatic procedure viewpoint. The Poznań Society for the Advancement of the Arts and Sciences, PL ISSN 0079-4740, pp. 39-52

The purpose of this paper is to analyze the primacy of communicative rationality in relation to other forms of rationality and to determine the status of openly strategic actions in the concept of Jürgen Habermas. In the theory of communicative actions, Habermas focuses on actions secretively strategic, recognizing them as "parasitic" in relation to communicative actions and explains the prevalence of communicative actions on the grounds of the theory of speech acts, in particular the concept of illocutionary force, the category of "social binding force", or practice in the lifeworld. By the same, Karl-Otto Apel challenges Habermas that he has skipped explicitly strategic class of actions, which entails the inadequacy of the justification for the status of communicative rationality. This raises a doubt - why should non-strategic actions take precedence over strategic ones? Karl-Otto Apel replies to this question with the help of transcendental-pragmatic procedure of an ultimate justification.
\end{abstract}

Keywords: rationality, strategic actions, communicative actions, universal pragmatics, the theory of speech acts

\section{Introduction}

Universal, or as later defined by Jürgen Habermas, formal pragmatics try to satisfy philosophical considerations around the concept of rational action. The analysis of human actions, their cognitive status, legitimacy, and conditions of occurring have become one of the main jobs for philosophy in the twentieth century. Habermas' considerations fit in this orientation. The interpretation of human actions based on the communicative theory provides a basis to formulate communicative concept of rationality, which in the author's intention is to become an alternative for the instrumental rationality. In Habermas position, the rationality of subjects is rooted in the rules of social life, which are determined by the possibility of intersubjective sharing of meanings. In line with this position, even 
a reflective attitude of each actor to themselves is marked by the possibility of an internal discourse with potential attitudes of others towards problematic issues (Habermas 1997: 52). This thesis expresses a fundamental paradigmatic change in the understanding of rationality. It is a transfer from rationality understood intentionally as for instance in casual theory by Donald Davidson (2002) to the rationality of intersubjective communicative actions.

According to Habermas or Karl-Otto Apel, rationality results directly from the nature of the language, from double proposition and performative structure of speech acts, of course understood in the spirit of the concept of John L. Austin and John Searle. On the ground of Habermas' universal pragmatics, within which the philosopher examines both the theory of speech acts and communicative competence of language users, it is possible to formulate the concept of communicative rationality. The rationality in Habermas' project will be considered in the context of claims made with every linguistic action to intersubjective validity (validity claims). However, in this perspective, strategic actions become problematic, when at least one party does not respect (secretly or openly) indicated validity claims. Although even in relation to the strategic actions, we can talk about reaching a consensus, or on the recognition of sound reasons, in this case, there is no room to accept legitimate arguments (Apel 2009: 286). This does not change the fact that the strategic rationality is an integral element of communication and as such it must not be separated from the communicative rationality.

Habermas examines the rationality from the perspective of actions undertaken by the actor that are set out in the context of the social life rules. In this way, he distinguishes cognitive and instrumental, expressive and aesthetic, practical and moral and communicative rationality (1984). Within the action, understood as a social action, there are two types of rationality, which are the subject of these considerations - communicative and strategic rationality. Habermas assumes that communicating oriented to achieve a consent or else actions motivated by communicative rationality make up a constitutive form of actions. In this sense, strategic actions constitute only a secondary function of social actions. According to Habermas;

the use of language with an orientation to reaching understanding is the original mode of language use, upon which indirect understanding, giving something to understand or letting something be understood, and the instrumental use of language in general, are parasitic. In my view, Austin's distinction between illocutions and perlocutions accomplishes just that (1984: 288).

\section{The concept of rationality of actions}

Addressing the issue of social action, Habermas modifies the concept of Max Weber, for whom an action can be described as "social" if it is oriented at the behaviour of other people. Accordingly, not all actions are of social nature. For example, a collision of two cyclists, is not of this nature unless the event is accompanied by a desire to go past or to exchange opinions. Nor is in this sense social action, a simultaneous operation of many people, if the action is not accompanied by the focus on the other person. We- 
ber's example in this field is a simultaneous opening an umbrella on a rainy day by many people. Unless this action is oriented to another person, this cannot be referred to as social action (Weber 1978: 22, 23). Weber distinguishes the following types of action instrumentally-rational, value-rational, affectual and traditional action (1978: 24, 25).

A vast majority of affectual and traditional actions are located outside of conscientiously oriented actions which "make sense". Value-rational actions are rational in view of the values that underlie this type of action. Thus, the rationality of these actions is limited to a large extent. Analyzing the concept of rationality, we can see that instrumentally-rational actions are of particular importance, as it is with them that Weber connects directly the concept of rationality. They are instrumental actions, oriented at achieving a specific objective while selecting appropriate measures, the consequences, even side effects taken into account. It is evident that a purely instrumentally-rational action, accompanied by an absolute instrumental rationality is only a construct, an "ideal type". In reality, various types are mixed in actions (Weber 1978: 24, 25). The typology of actions, rationality and discourses of Habermas are analogous.

Distinguishing communicative, teleological, drama actions or those dealt with in standards, Habermas proves that the range of rational actions is much wider. The indicated types of actions correspond to a specific type of rationality. In this way, Habermas distinguishes respectively the communicative, instrumental-cognitive, expressive and aesthetic and moral and practical rationality. The attribution to a particular type of action and the corresponding rationality depends on the capability to fulfil the specific intersubjective validity claim and on referencing the subject of action to one of the worlds - subjective, social, or objective. In this way:

Rationality is understood to be a disposition of speaking and acting subjects that is expressed in modes of behavior for which there are good reasons or grounds. This means that rational expressions admit objective evaluation. This is true of all symbolic expressions that are, at least implicitly, connected with validity claims (or with claims that stand in internal relation to criticizable validity claim) (Habermas 1984: 22).

Thus, rationality is considered from the communicative perspective and its range is not narrowed down to instrumentally-rational actions. Intersubjectivity of the communicative process ensures that all forms of conduct whose good reasons proving them, the subject is able to indicate, may be considered rational.

Habermas distinguishes three levels of reference for human actions. The first is the physical reality. Within its framework, the actors undertake teleological action, or else instrumentally-rational interference into the outside world. In this model, social interactions are also perceived analogically with the objects of the physical world, as people are treated instrumentally, as a measure to meet specific targets (Habermas 1986: 24). At the plane of social action, Habermas distinguishes both communicative and strategic actions (1984: 285). In this model, subjects mutually coordinate their actions in the light of intersubjective social rules. The knowledge at the propositional level is the determinant of actions related to the social order. Whether we are dealing with communicative or strategic action, this depends on the fact whether the knowledge is shared by all the partners of interaction, that is, whether it serves the agreement, or on the contrary, is 
oriented unilaterally. These actions are differentiated, therefore, by the knowledge embodied by the participants of the interaction. It needs emphasizing that the agreement is understood here as recognition of intersubjective validity claims (Habermas 1986: 22, 23). Therefore, we can assume that when the knowledge of subjects serves to mutual coordination of actions oriented at an agreement, they pursue a communicative action. This knowledge also means that the participants of interaction have reasons to justify the action undertaken.

The fundamental assumption of non-strategic actions is the orientation of entities at agreement. It is the consensus, if any, that determines the meaning and scope of rational social actions in this model. Quite contrary to them, strategic actions are determined by rivalry for success. Actions governed by standards or drama actions are oriented at agreement even if they are unilateral in nature, and by the same match the model of non-strategic actions. With reference to strategic actions, Habermas assumes their graduality. In this way we can distinguish open and secret strategic actions that include both manipulation as well as systematically distorted communication. In the case of secret strategic actions, at least one of the participants in the interaction retains exclusively appearances of agreement-oriented action, actually pursuing their goal. Thus, this action is based on the ignorance of other participants on the actual objective of the interaction (Habermas 1984: 332, 333).

\section{Strategic actions in the context of intersubjective validity claims}

To distinguish agreement-oriented action from strategic ones, focused on the implementation of a specific target, by imposing influence, the formal and pragmatic analysis of speech acts shall be referred to. The universal pragmatics task is to reconstruct the language interaction so as to establish universal conditions for understanding, if any (Habermas 1979: 1). In this way, Habermas undertakes to analyse the speech act theory of John L. Austin and John Searle and to make research on communicative skills of language users in the framework of universal pragmatics. At the same time, Habermas modifies Austin's concept of speech acts. He accepts his distinction of speech acts as locution, illocution and perlocution, but embeds them in the context of communicative rationality. In this way, he explores the layers of speech acts in terms of the coordination of actors involved in the interaction already indicated, if any.

The key to understanding the agreement as a mechanism of coordination is to refer to intersubjective validity claims postulated by Habermas. According thereto, the participants of the interaction mutually recognize the legitimacy of the claims reported while communicating and related to at least one of the worlds: the objective world in the event of a claim to the truth as part of the teleological actions, the subjective world in the event of problematizing the claim to sincerity in the drama actions; the social world by filing the equity claim at the plane of actions regulated by the norms. By the same, each communicative action requires that the subject adopts a reflective attitude relativised by the right of interaction partners to challenge the validity. In the case of agreement-oriented action, the actors present their attitude to all these worlds, i.e. social, subjective 
and objective and report the legitimacy of all four intersubjective validity claims. This means that agreement-oriented actor, at least implicitly declares that their statement is true, sincere, and their action is right because of the normative context (or the context itself is legitimate) (Habermas 1986: 32, 33).

That means that,

The speaker must choose a comprehensible [verständlich] expression so that the speaker and the hearer can understand one another. The speaker must have the intention of communicating a true [wahr] proposition (or a propositional content, the existential presuppositions of which are satisfied) so that the hearer can share this knowledge of the speaker. The speaker must wont to express his intentions truthfully [wahrhaftig] so that the hearer can believe the utterance of the speaker (can trust him). Finally, the speaker must choose an utterance that is right [richtig] so that the hearer can accept the utterance and speaker and hearer can agree with one another in the utterance with respect to recognized normative background. Moreover, communicative action can only continue undisturbed as long as participants suppose that the validity claims they reciprocally raise are justified (Habermas 1979: 2, 3).

The claim to truth, truthfulness and moral validity highlighted by Habermas correspond to the formal and pragmatic functions of language, or else to representing something in the world, to legitimizing interpersonal relations and manifesting the speaker's intentions (Cyrul 2005: 212).

According to Karl-Otto Apel, the way of understanding the basic concepts of philosophy must be changed, which is facilitated by understanding the rationality through the prism of language and communicative actions. For instance, the search of meaning shall be done in philosophy by seeking the terms of legitimacy and not of veracity. This attitude is possible, taking into account the fact that the language itself constitutes the intersubjectively valid meaning. But one cannot close exclusively in the language analyses as was done by the analytic philosophy of language, which committed thereby a mistake of abstractive fallacy (Apel 2009: 270-273). And yet, it follows that the truth shall be understood as one of the dimensions of intersubjectively shared legitimacy of the meaning articulated in the language. However, the meaning must not be understood exclusively as a representation or description of the states of affairs in propositional sentences, which was clearly exposed in the theory of speech acts by John L. Austin (Apel 2009: 274). Speech acts have a double performative-propositional structure. This also applies to affirmative sentences. While the propositional part of the speech act refers to a specific state of affairs and can remain unchanged, the performative part determines the illocutionary force of speech act, uttered in certain contextual conditions (Apel 2009: 275). According to Apel, in this perspective, it is understandable, why the performative part of speech acts cannot be analyzed from the point of view of veracity, but only of legitimacy, understood, at the same time, as conditions of acceptability (Apel 2009: 276). This view is fully shared by Habermas.

Thus, Habermas refers the indicated intersubjective validity claims to the theory of speech acts. Following Austin, Habermas assumes that the speech act is not just saying something, but an action, a deed, whose illocutionary force can be described. Moreover, one can distinguish a special class of language actions, referred to as perlocutionary. 
which are done with the intention to cause determined effects in the sphere of action, feelings and thoughts of co-speakers (Austin 1962: 98-104). Thus, Habermas assumes, that the act of speech means "to say something, to act in saying something, to bring about something through acting in saying something" (Habermas 1984: 289). From the point of view of strategic actions, it is the perlocutions that are of particular importance. The double, propositional and performative structure of speech acts validates the validity claims which Habermas tries to demonstrate on the ground of universal pragmatics postulated thereby. Illocutionary element of speech act, which is determined by a performative sentence built in the first person of present tense in the indicative mood, with the direct object in the second person is supplemented by a propositional component, including a referral and indicative phrases (Cyrul 2005: 211). The agreement between partners must take place on both levels, i.e. performative and propositional. In this way, the commitments contributed in the illocutionary layer of speech act are legitimate, if they can be cognitively verified or recognized within intersubjective validity claims (Cyrul 2005: 212) as, according to Habermas:

In the final analysis, the speaker can illocutionarily influence the hearer and vice versa, because speech-act-typical commitments are connected with cognitively testable validity claims - that is, because the reciprocal bonds have a rational basis. The engaged speaker normally connects the specific sense in which he would like to take up an interpersonal relationship with a thematically stresses validity claim and thereby chooses a specific mode of communication (1979: 63).

Habermas assumes that we understand a speech act if we know the factors that make it acceptable. The acceptability category determines, at the same time, the conditions necessary for the interaction partner to take the "Yes" position in relation to the claims raised by the speaker. The rationality of actors is measured by their ability to defend, cite appropriate reasons to support the postulated position, to undertake action. The essential feature of claims formulated by interlocutors is the possibility to subject them to criticism and justify them (Habermas 1984: 8, 9). Thus, the strength of language action results from the assumption that the subject of the action takes seriously the commitments raised together with validity claims, since, if needed, they have to give reasons to defend the intentions filed in the illocutionary layer of speech act. The illocutionary effect is not guaranteed by the legitimacy of the speech act, but the surety that if needed, the claim that has been raised with this act will be fulfilled. Thus, the illocutionary effect is confirmed by the possibility to justify the validity claim by appropriate reasons filed with the speech act (Habermas 1984: 302, 303).

The understanding of sentences in terms of legitimacy and acceptability does not seem to be problematic in the case of directive speech acts, e.g. in the event of orders or promises. Their addressee shall know not only the conditions for the fulfilling of propositional element but also the conditions of legitimacy or acceptability in which they acquire their illocutionary force. Therefore, this means, that the addressee needs to realize the performative part of the speech act. According to Apel, this is also necessary in the case of assertorial sentences whose purpose is to express a defined judgement. The addressee shall know not only the conditions of propositional content of a given judgement, but also expect that claiming something, the speaker feels authorized to do so. The ad- 
dressee also understands that the speaker expects from him the acceptance or challenge of the judgement expressed with the use of reasons. According to Apel, this confirms, that also in the case of assertorial sentences, the performative part is understood in terms of legitimacy or acceptability (Apel 2009: 278). However, while in the case of assertorial sentences, the propositional content remains in agreement with the fulfillment of validity claims, but with reference to directive sentences, putting into life the conditions of truth related to propositional content, e.g. to meet the demand, will not entail the need to meet validity claims reported in the performative layer. This case confirms, for instance, the performance of an order for opportunistic motives when its addressee in the light of their own system of values considers the order to be immoral, but nevertheless they perform it, because they are afraid of consequences, or expect advantages for the performance of the order (Apel 2009: 278). Strategic actions are as problematic in this perspective.

\section{Communicative and strategic actions as illocutions and perlocutions}

Communicative rationality is contained already in the illocutionary layer itself of speech acts, however, it goes beyond the language actions. Communicative rationality covers by its range, all social actions and interactions. The language action alone does not exhaust the notion of communicative rationality as strategic actions, although they take place in a language but they do not reflect the communicative rationality. The coordination of actions at the level of a strategic use of language is not oriented at having an agreement, but only at achieving the desired results, the effects of the language being used. For this reason, Habermas argues that the proper reference of strategic actions analyses are perlocutions (1986: 66). Habermas suggests the following definition of the communicative actions:

Thus I count as communicative action those linguistically mediated interactions in which all participants pursue illocutionary aims, and only illocutionary aims, with their mediating acts of communication. On the other hand, I regard as linguistically mediated strategic action those interactions in which at least one of the participants wants with his speech acts to produce perlocutionary effects on his opposite number (1984: 295).

Thus, the communicative rationality is referred only to the illocutionary layer of actions for which intersubjective validity claims are in force. Furthermore, partners of interaction are oriented to achieving consensus. In the case of strategic actions, perlocutionary effects dominate over the illocutionary content. "Binding force appropriate for illocutionary acts" is suspended for the perlocutionary effects (Habermas 1997: 68).

Furthermore, Habermas distinguishes three types of perlocutionary effects. They may be the consequences, arising grammatically from the content of the illocutionary act, where, for example, the promise will be kept or the intention announced will be put into life. Another type are contingent consequences of communicative actions, which occur depending on the context as a result of the illocutionary effects. An example can be 
a surprise, a doubt or terror in response to a given action. Finally, a separate class of perlocution are unaware consequences of secret strategic actions (Habermas 1997: 69).

According to Habermas, strategic actions as perlocutions are "parasitic" in relation to communicative actions in such a sense that their effectiveness is based on the understanding and use of communicative actions. The actor of strategic action does not want with the help of illocutionary effects to achieve agreement, but to have an impact on the hearer, to accomplish a specific purpose, etc. This does not change the fact that the effectiveness of perlocution is contained in the selection of relevant illocutionary content. This means that the actor, acting strategically must cause his interlocutor's belief that at the illocutionary level, they refer to the validity claim. If the speaker wants to be successful by means of rhetorical measures, they must cause the listener's impression that they use arguments (Apel 2009: 296). In this very context, strategic actions are only parasitic and communicative actions make up the primary mode of language use. For the effective putting into life of strategic actions, both the knowledge and understanding of the language rules and intersubjective validity claims are required. However, in the case of strategic actions, the claims are suspended. Accordingly, Habermas emphasizes that

to this extent, what we initially designated as "the use of language with an orientation to consequences" is not an original use of language but the subsumption of speech acts that serve illocutionary aims under conditions of action oriented at success (1984: 293).

Similarly, one can come to the conclusion that since the actor, acting strategically, is aware that the effectiveness of their action depends on the impression made on the interlocutor that arguments are used, then they also admit the prevalence of communicative actions. They recognize, at least implicitly, that the strategic actions are parasitically dependent upon the communicative use of language. According to Apel, this is what allows Habermas to assume that strategic action is quite normal in everyday communicative practice (Apel 2009: 297).

\section{Communicative rationality and the lifeworld}

Non-strategic and strategic actions exclude each other. No situation is possible where communication both in order to reach an agreement and to impose an impact can take place at the same time. "The agreement", through coercion, intimidation, threats, etc. cannot be understood as agreement (Habermas 1986: 23). Strategic actions, as already indicated, belong to the class of social actions, however, they are a part of the instrumentally-rational action model. The mechanism of action coordination is not an agreement but a desire to exert an impact. In this way, interactions do not differ from the manipulation of physical objects. Thus, strategic actions do not serve to maintain social order, but only to support the instrumental order. The fundamental reference of action coordination within the instrumental order is, according to Habermas, the relationship of power and subordination based on the economic and political mechanisms. An important factor to continue instrumental governance are therefore money and power. These are communicative media, which outside the language serve to coordinate action beyond the 
lifeworld. Competition for them pushes interactions into the area of strategic action (Habermas 1986: 25). In this way, we touch a very important factor to distinguish strategic actions from communicative ones. In contrast to non-strategic actions, strategic forms of communication do not serve the symbolic reproduction of the lifeworld (Habermas 1986: 42).

Habermas assumes that communicative rationality takes precedence over strategic rationality. This means that despite of the existence of other human interaction forms, it is the communicative (and not, for example strategic) use of language that is essential. This statement seems to be rather problematic, in particular, if we analyse the discourses in the media, or politics. By analyzing interactions in terms of strategic components, we are willing to admit their superiority. In this perspective, the age of propaganda is even mentioned (Pratkanis \& Aronson 2005: 14). Habermas analyzes the range of the concept of rationality by referring it to language actions. In this way, the philosopher creates a concept of society based on the theory of language. This aspect is particularly emphasized by Charles Taylor, who analyzes the Theory of communicative action in terms of complementarity of the structure of language and speech acts. The duality understood in this manner also allows Habermas to distinguish two mutually complementary elements of society, or else the system and the lifeworld (Taylor 1988: 35-37).

According to the intention of Habermas, the worldlife makes up each background of our daily interactions. In this way, we do not have to problematize the whole contexts and references to a given situation, as they become familiar through the joint participation in the same lifeworld. Only segments of new situations are problematized, although even those are embedded in a horizon already defined, "known". In this way, conflict-free and unproblematic everyday life goes on, primarily focused on agreement. Analyzing the strategic use of language, we realize only controversial section of the interaction, which constitutes a small percentage compared to the countless interactions in the lifeworld. This assumption is based on the belief that the lifeworld offers a wide hidden consensus (Habermas 1986: 39), and reaching an agreement itself, or else the main postulate of communicative actions, is the telos of human language. That is why a majority of interactions between actors are non-strategic actions. Thus, Habermas perceives the rationalization of the lifeworld through the prism of the possibility to reach an agreement by communication. In this way, according to Habermas,

a lifeworld can be regarded as rationalized to the extent that it permits interactions that are not guided by normatively ascribed agreement but - directly or indirectly - by communicatively achieved understanding (1984: 340).

On the basis of the lifeworld, daily communication and interactions go on that serve to coordinate social actions. The agreement is reached within validity claims which are understood and accepted. The radicalization of arguments and critical reflection over validity claims are possible at the level of argumentative discourse. Thus, understood but not accepted validity claims are subject to thematisation within the radicalization of arguments in the discourse (Apel 2009: 290).

At the level of everyday communication, not only the context of all utterances but the broad background in which they are embedded are also important. The background 
are the collectively shared resources of speakers' knowledge on the surrounding world (background knowledge). This knowledge is a pre-reflective horizon, raising no doubt of all convictions of communication participants and hence, it is also the foundation of possible acts of communication, if any, in general. This knowledge is of holistic structure, which means that its individual elements refer to each other. Ultimately, this knowledge is not explicitly articulated. Philosophical attempts to explicate it are possible only in the form of common sense certainties (Habermas 1984: 336). In this perspective, the lifeworld and communicative actions mutually assume and complement each other. And yet it is precisely in this perspective, that Karl-Otto Apel doubts whether the communicative rationality status can be embedded in agreement, resulting from the assumption of impassability related to unquestioned lifeworld certainties (Apel 2009: 294).

According to Apel, the assumption that in the lifeworld most of the interactions are of communicative nature is false. Social actions are coordinated just as often by means of strategic action as the communicative ones and to ignore this fact can lead to idealistic fallacy. Similarly argues Taylor, for whom it is incomprehensible why people would seek agreement as a guiding principle of coordinating actions (1988: 45). However, attention shall be turned, as Andrzej Maciej Kaniowski does, to the differences in the perception of language and understanding by Habermas and Taylor. In the case of Taylor, the emphasis is imposed on the contents of speech utterance, on the topic of the conversation, while Habermas underlines the structural and formal aspects of language, in particular claiming, and meeting claims to intersubjective validity (Kaniowski 2003: 45).

According to Apel, incorrect, idealistic assessment of the primacy of non-strategic actions results from insufficient exposure to explicitly strategic actions. In this perspective, Habermas' arguments on parasitic nature of strategic actions can have their application only to actions secretly strategic. According to Apel, Habermas has not shown that on the ground of lifeworld, the actions openly strategic are factually normal, but has only proved the fact that the primacy of the normative use of language has been recognized, which, moreover, is not the language secretly strategic. Furthermore, according to Apel, Habermas has not shown that, in relation to openly strategic rationality (e.g. within the context of public authority) normative primacy of validity claims has been recognized because of necessity (2009: 297).

\section{Status of strategic rationality and the idea of ultimate justification}

James Johnson imputes Habermas a similar error in his understanding of rationality, which he wants to overcome himself. Habermas recognizes that one-sided narrowing of rationality to the cognitive and instrumental rationality prevails in philosophy. The mere replacement of the privileged position of teleological actions with communicative ones does not change the one-sided look on rationality. Furthermore, it introduces a false picture of strategic rationality. The recognition that the strategic actions are parasitic to communicative actions is also problematic. According to Johnson the understanding of strategic actions as residual within the typology of actions by Habermas gives rise to difficulties. According to Johnson, erroneous understanding of strategic actions results 
from the attempts to explicate communicative actions as superior ones. A look at the strategic actions through the prism of communicative ones resulted in distorted, too negative picture of strategic rationality (Johnson 1991). However, it needs underlining that recognizing the primacy of communicative rationality, Habermas does not intend to depreciate the strategic rationality but to justify the status of communicative actions in the epistemological structure. The intention of Habermas is not so much the description of strategic communicative practices but an indication that rationality potential lies in the language. This potential exists in the validity claims of any language act. It follows that every communicative act is necessarily rational.

Karl-Otto Apel agrees with Habermas as to rationality being present in the communicative practice. However, he does not accept Habermas' argument to justify communicative rationality by referring to the illocutionary force and practices in the lifeworld. In this way, Apel shares Habermas' thesis on the primacy of non-strategic actions, however, he doubts its justification. Contrary to Habermas, he assumes that the rationality inherent in the communication shall be justified by reference to the transcendental and pragmatic procedure. The philosopher understands by this the specific transformation of transcendental philosophy of Immanuel Kant through widely understood pragmatic and semiotic philosophy, with particular emphasis on Charles Sanders Peirce's concept. According to the transformation philosophy postulated by Apel, he proposes to seek the validity and legitimacy conditions in the very act of argumentation, or else at the plane of argumentative discourse.

According to Apel, the primacy of communicative actions over openly strategic ones cannot be proven by reference to the practice in the lifeworld. Why should we assume that the actor, acting openly strategically recognized necessarily the primacy agreement-oriented action, since he had already renounced even secretly strategic actions? In Apel's opinion only the reflection on the irrefutable presuppositions of argumentative discourse may prove the primacy of non-strategic rationality. The discourse rationality contained in the language constitutes an alternative for openly conflict situations, the position of force or open strategy.

The reasoning is essentially rational and entails the necessity to recognize at least implicitly discourse normative assumptions. The thesis of ultimate justification put forward by Apel stipulates, moreover, that arguer under threat of committing a performative contradiction cannot say that the rules of reasonable argument do not apply thereto. The actor, arguing in favour of such a thesis enters already into the plane of argumentative discourse. The category of performative contradiction determines, by the same, the conflict between the illocutionary content and the performative text. Thus, Apel assumes that the argumentative situation is impassable. According to Apel,

whoever argues in favor of this preparational decision must show that it is untenable; for by his or her very arguing he or she necessary already lays claim on the inter-subjective validity of argumentative rationality [...]. It turns out that, while arguing, one cannot, in principle, get behind the rationality of arguing: this rationality is non-circumventible (nichthintergehbar). And this means: there is no philosophical standpoint of pure subjectivity that would be situated even prior to the inter-subjective validity of argumentative rationality. Any attempt at disputing this must lead into a performative self-contradiction (1998: 237, 238). 
Therefore, arguing the subject of action by the mere fact of arguing, is in favour for the rationality inherent in the argument. One must emphasize that the thinking is also a form of internalized argument. The idea on the impassability of argumentative discourse, according to Apel, makes up a transcendental and pragmatic transformation of the philosophy of Immanuel Kant, because it expresses a synthetic judgement, which has an a priori validity (Kuhlmann 2007: 237). Thus, Apel with the help of the ultimate justification thesis determines the conditions of knowledge possibility and legitimacy, as well as, the conditions of the possibility of normative ethics. However, Habermas refuses to agree with the thesis (1998: 349-353).

The thesis of the ultimate justification for the discourse rationality allows Apel to assume that anyone who wants to argue seriously (even as a skeptic or opting for the position of force) must adopt certain normative rules of discourse. This means that a reflection on unchallenged assumptions of argumentative discourse makes the parties to the conflict aware that problematic situations cannot be solved through strategic actions. In this way, according to Apel, the parasitic nature even of openly strategic actions can be justified. The argumentative discourse undermines the sense of strategic actions, because it exposes their true nature (Apel 2009: 300, 301).

The arguments in favour of discourse rationality are coupled in Apel's project with ethical considerations. In this way, discourse communicative rationality underlies ethics, because the claim to truth involves at least an implicit claim to moral honesty and fairness. Thus, Apel refers to the assumption of an ideal communicative community adopted as a contrfactually anticipated ideal and guarantee of discourse legitimacy $(1992: 13,14)$. The ideal communicative community, in contradiction to the real one determined by the situational context, obliges all members of the community by way of universalization to comply with, or at least to be aware of the fundamental moral norms. Apel includes to them equal rights of all members and co-responsibility for formulating and solving problems (2002: 75). By the same, the ideal communicative community protects the discourse against the strategy, because it results from the very communicative rationality. In this way, according to Apel,

it turns out as a result of the transcendental-pragmatic self-reflection of the rational discourse that there must be a unity of discourse rationality, and hence of communicative and ethical rationality that is different from strategic rationality (1996: 329, 330).

\section{Conclusions}

By his project of Habermas position's radicalization, through transcendental reflection on irrefutable assumptions of argumentative discourse, Apel as he claims himself, wants to create a bridge between the concept of Habermas and his own transcendental-pragmatic project (1996: 317). Apel assumes that in the case of human relationships, it is only on the ground of reflection on irrefutable discourse assumptions that the impossibility to reduce rationality to instrumental or strategic rationality can be proven. At the plane of human relationships, the strategic rationality is not only a transposition of in- 
strumental rationality and it must not be justified in these terms. Accordingly, in Apel's position, communicative rationality constitutes the basis of understanding and justification of human rationality (2009: 303). According to Apel,

Thus it turns out, $[\ldots]$ that the only serious candidate for the role of representing the overarching type of communicative rationality, and thereby of human rationality in general, is indeed the consensual communicative rationality, which becomes explicit on the level of argumentative discourse (1996: 336).

The project by Apel itself, in particular, through the final justification thesis raises considerable controversies. However, both the philosophy by Habermas and by Apel makes up a rehabilitation of the unbalanced position of rationality by embedding it within the limits of language. Formal and pragmatic analyses of the structure of language and its communicative character allow both philosophers to formulate the concept of communicative rationality inherent in the very nature of human language ability.

\section{References}

Austin, John L. 1962. How to do things with words. Oxford: Clarendon Press.

Apel, Karl-Otto. 1992. Etyka dyskursu jako etyka odpowiedzialności - postmetafizyczna transformacja etyki Kanta. (The ethics of discourse as the ethics of responsibility - the transformation of post-metaphysical ethics of Kant) Principia: Pisma Koncepcyjne z Filozofii i Socjologii Teoretycznej 5. 5-37.

Apel, Karl-Otto. 1996. The Rationality of Human Communication: On the Relationship between Consensual, Strategic, and Systems Rationality. In Selected Essays. Ethics and the Theory of Rationality. New Jersey: Humanities Press.

Apel, Karl-Otto. 1998. The self-recuperative principle of a critical-hermeneutic reconstruction of history. In From a transcendental-semiotic point of view. Manchester, New York: Manchester University Press.

Apel, Karl-Otto. 2002. Anwendungsprobleme der Diskursethik. (Application problems of discourse ethics) In Apel, Karl-Otto \& Niquet, Marcel (eds.), Diskursethik und Diskursanthropologie. Aachner Vorlesungen. Freiburg, München: Verlag Karl Alber.

Apel, Karl-Otto. 2009. Znaczenie językowe, prawdziwość i normatywna prawomocność. Społeczna moc wiążąca mowy w świetle transcendentalnej pragmatyki języka. (The language meaning, truthfulness and normative legitimacy. Social binding force of speech in the light of transcendental pragmatics of language) In Rasiński, Lotar (ed.), Język, dyskurs, społeczeństwo, 269-303. Warszawa: WN PWN.

Cyrul, Wojciech. 2005. Problem ważności w habermasowskiej teorii uniwersalnej pragmatyki. (Habermasian theory of Universal pragmatics and its discoursive validity) Ruch Prawniczy, Ekonomiczny $i$ Socjologiczny 2. 209-221.

Davidson, Donald. 2002. Essays on Actions and Events. Oxford: Clarendon Press.

Habermas, Jürgen. 1979. What Is Universal Pragmatics? In Communication and the Evolution of Society. Boston: Beacon Press.

Habermas, Jürgen. 1984. The theory of communicative action. Reason and the rationalization of society, vol. 1. Boston: Beacon Press.

Habermas, Jürgen. 1986. Pojęcie działania komunikacyjnego. Uwagi wyjaśniające. (The concept of communicative action. Explanatory Notes) Kultura i Spoleczeństwo 3(30). 23-44.

Habermas, Jürgen. 1988. Entgegnung. In Honneth, Axel \& Joas, Hans (eds.), Kommunikatives Handeln. Beiträge zu Jürgen Habermas' Theorie des kommunikativen Handelns. Frankfurt am Main: Suhrkamp.

Habermas, Jürgen. 1997. Pojęcie racjonalności komunikacyjnej w świetle teorii aktów mowy. (The concept of communicative rationality in the light of the theory of speech acts) In Buksiński, Tadeusz (ed.), Rozumność i racjonalność, 51-77. Poznań: Wydawnictwo Naukowe IF UAM.

Johnson, James. 1991. Habermas on strategic and communicative action. Political Theory 2(19). 181-201. 
Kaniowski, Andrzej M. 2003. Charles Taylor i Jürgen Habermas a sposób widzenia języka przez Wilhelma von Humboldta. (Charles Taylor and Jürgen Habermas, and the way of seeing the language by Wilhelm von Humboldt) In Sierocka, Beata (ed.), Via communicandi. Przetom komunikacyjny a filozoficzna idea konsensusu. Wrocław: Oficyna Wydawnicza Atut.

Kuhlmann, Wolfgang. 2007. Refleksyjne ostateczne uzasadnienie. Przyczynek do tezy o nieprzekraczalności sytuacji argumentacyjnej. (Reflective ultimate justification. Contribution to the thesis on impassability of argumentative situation) In Sierocka, Beata (ed.), Via Communicandi. Wspólnota komunikacyjna $w$ teorii i praktyce. Wrocław: Oficyna Wydawnicza Atut.

Pratkanis, Anthony \& Aronson, Elliot. 2005. Wiek propagandy. Używanie i nadużywanie perswazji na co dzień. (Age of Propaganda. The everyday Use and Abuse of Persuasion) Warszawa: WN PWN.

Taylor, Charles. 1988. Sprache und Gesellschaft. In Honneth, Axel \& Joas, Hans (eds.), Kommunikatives Handeln. Beiträge zu Jürgen Habermas' Theorie des kommunikativen Handelns. Frankfurt am Main: Suhrkamp.

Weber, Max. 1978. Economy and Society. An Outline of Interpretative Sociology. Berkeley, Los Angeles, London: University of California Press. 